\title{
Scientific production of researchers in the Nutrition field with productivity fellowships from the National Council for Scientific and Technological Development
}

\author{
Perfil e produtividade de pesquisadores da \\ área de Nutrição bolsistas do Conselho \\ Nacional de Desenvolvimento \\ Científico e Tecnológico
}

Lucinéia de $\mathrm{PINHO}^{1}$

Hercílio MARTELLI-JÚNIOR ${ }^{1}$

Eduardo Araujo OLIVEIRA ${ }^{2}$

Daniella Reis Barbosa MARTELLI ${ }^{1}$

A B S T R A C T

\section{Objective}

To characterize researchers in the Nutrition field awarded with Conselho Nacional de Desenvolvimento Cientifico e Tecnológico research productivity fellowships and evaluate their scientific production according to an analysis of curricula registered on the Lattes Platform.

\section{Methods}

The study is cross-sectional and descriptive in scope, and was developed from October 2014 to February 2015. The productivity fellowships/Conselho Nacional de Desenvolvimento Cientifico e Tecnológico researchers were identified from the Lattes Platform, and their curriculum lattes were downloaded for data collation. Information on the profiles of the researchers and the bibliometric data of productivity (published articles, articles and citations registered on ISI/Web of Science and Scopus databases, impact of the publications, and academic advising) were collected.

\footnotetext{
1 Universidade Estadual de Montes Claros, Centro de Ciências Biológicas e da Saúde, Programa de Pós-Graduação em Cuidado Primário em Saúde. Campus Universitário Prof. Darcy Ribeiro, Vila Mauriceia, 39401-089, Montes Claros, MG, Brasil. Correspondência para/Correspondence to: L PINHO. E-mail: <lucineiapinho@hotmail.com>.

2 Universidade Federal de Minas Gerais, Faculdade de Medicina, Departamento de Pediatria. Belo Horizonte, MG, Brasil.
} 


\section{Results}

Eighty researchers were identified and evaluated. A total of $67.5 \%$ were female and $53.5 \%$ were classified as category 2. Approximately two-thirds (65.0\%) were located in Southeastern Brazil. The sum of articles published by the researchers from the beginning of their career until the end of the study came to 7,358 (median=84 per researcher, interquartile range $=53-285$ ). Of these publications, $45.0 \%$ were indexed in the Web of Science and $62.0 \%$ in Scopus. Of the journals where the articles were published, $70.0 \%$ had an impact factor.

\section{Conclusion}

Most publications were performed in journals with an impact factor, indicating the influence of Brazilian nutrition studies on society and their potential for guiding public policies on nutrition and health.

Keywords: Bibliometry. Nutrition. Research personnel.

\section{R E S U M O}

\section{Objetivo}

Caracterizar pesquisadores da área de Nutrição cadastrados como bolsistas de produtividade em pesquisa junto ao Conselho Nacional de Desenvolvimento Científico e Tecnológico e avaliar sua produção científica através da análise de currículos cadastrados na Plataforma Lattes.

\section{Métodos}

Trata-se de estudo transversal e descritivo, desenvolvido no período de outubro de 2014 a fevereiro de 2015. Os pesquisadores bolsistas produtividade em pesquisa/Conselho Nacional de Desenvolvimento Científico e Tecnológico foram identificados na Plataforma Lattes e seus currículos obtidos para coleta de dados. Foram coletadas informações do perfil dos pesquisadores e dados bibliométricos de produtividade (artigos publicados, artigos e citações cadastradas nas bases de dados ISIMeb of Science e Scopus, impacto das publicações e orientações acadêmicas).

\section{Resultados}

Foram identificados e avaliados 80 pesquisadores, $67,5 \%$ eram do sexo feminino e 53,5\% bolsistas na categoria 2. Aproximadamente dois terços $(65,0 \%)$ estavam localizados na região Sudeste do país. A soma de trabalhos publicados por eles do início da carreira até o término da pesquisa foi de 7358 (mediana=84 por pesquisador, intervalo interquartil=53-285). Desses, 45,0\% foram indexados no Web of Science e 62,0\% no Scopus. Dos periódicos das publicações, 70,0\% possuíam fator de impacto.

\section{Conclusão}

A publicação da maioria dos trabalhos em periódicos com impacto indica a expressão das pesquisas em Nutrição brasileiras para a sociedade e seu potencial em influenciar políticas públicas de alimentação e saúde.

Palavras-chave: Bibliometria. Nutrição. Pesquisadores.

\section{NTRODUCTIO N}

Nutrition is a multidisciplinary science, characterized by the integration of biological, social, and environmental dimensions [1]. According to The Global Nutrition Report [2], suitable food and nutrition are basic requirements for health promotion and protection, as well as for sustainable development. Adequate food is, in fact, an essential part of the hunger and poverty eradication programs of the World Health Organization, such as the Millennium
Development Goals [3]. Nutrition is, therefore, a fundamental area for the development of public policies and the agenda of international organizations focused on human development and the planet's sustainability [4].

Nutrition was only recognized as an area of knowledge by the Coordenação de Aperfeiçoamento de Pessoal de Nível Superior (CAPES, Coordination of Improvement of Higher Level Personnel) in 2011. Today, it is included among the 48 areas that make up the National Graduate System [5] and, although a complex 
and heterogeneous area, its study has been expanding in the country [6]. In 2016, CAPES listed 28 programs and 40 postgraduate programs specifically associated with the area of nutrition. The latter comprises 25 masters, 12 PhDs, and 3 professional masters' programs [5]. This growth has been followed by a significant increase in Brazilian academic production in the field of Nutrition [7]

The investment policies focused on Brazilian researchers have also contributed to research advances in Nutrition. Among the incentives is the Productivity Research Grant provided by the Conselho Nacional de Desenvolvimento Científico e Tecnológico (CNPq, National Council for Scientific and Technological Development). According to the normative criteria established by CNPq, productivity research grants are classified into three levels: Level 1, Level 2, and Senior, with Level 1 being subdivided into four categories: 1A, 1B, 1C, and 1D [8]. As recognized by the government and the scientific community, researchers with productivity research grants should be systematically evaluated. Such a continuous analysis allows for the development of tools for the definition of guidelines, allocation of investments and resources, program formulation, and evaluation of activities related to scientific and technological development according to each activity area in Brazil [9].

Several studies [10-16] have analyzed the profiles and scientific production of researchers with productivity research grants in different areas of knowledge. The bibliometric indicators used in these studies include the number of people who have received academic or scientific qualifications, the number of patents registered by scientists, the number of scientific articles published, the number of scientists who have published scientific articles, the number of bibliographical references cited in scientific articles, the number of citations per scientific article, the number of research grants awarded to scientists, and the amount of resources allocated to the research activities promoted by the various agencies [17]. It is also important to know the profile of the researchers and to examine their area of research, professional experience, and contribution to training new professionals. However, there are still no quantitative or qualitative indicators for the scientific productivity of researchers in the field of Nutrition in Brazil [18].

Nutrition is a strategic area for the development of teaching and research as well as for public health, where professionals are active in Primary Health Care teams. Therefore, knowledge of the scientific performance of researchers in Nutrition is key, both to analyze the current status of the area and to design future scenarios. In this context, this study is aimed at characterizing professionals in the field of Nutrition with productivity research grant/ $\mathrm{CNPq}$ grants and evaluating their scientific production through an analysis of curricula registered on the Lattes Platform.

\section{METHOD}

This is a cross-sectional and descriptive study, developed between October 2014 and February 2015. The data were obtained during the period of the study from the curricula of professionals identified from the productivity research grant/CNPq grants list available on CNPq's website [17]. The following search filters were used: Country=Brazil; States=All; Institutions=All Institutions; Large Areas=All Large Areas; Areas=Nutrition; Modalities=Productivity in Research; Levels=All Levels. The curricula of 80 researchers available on CNPq's [19] Lattes Platform were analyzed. The curricula were checked to determine whether they were up to date.

The curricula were then analyzed to characterize the researchers and collect bibliometric data regarding their scientific production, following previous studies $[10-13,20]$. The characterization of the researcher consisted of determining 
their gender, degree, the type of grant $(2,1 \mathrm{~A}$, 1B, 1C, 1D or senior) received, the federative unit (professional address), the institution and country where the PhD (stricto sensu) was obtained and the postdoctoral studies were developed, the number of years of experience after completing their PhD (stricto sensu), and the research area based on the categories of the Lattes Platform (Nutrition, Biochemistry of Nutrition, Epidemiology, Public Health, and Maternal and Child Health). Analysis of the ratio of the number of productivity research grant fellows per inhabitant of each state was also performed based on Instituto Brasileiro de Geografia e Estatística data [11,21].

Scientific production was determined by each researcher's number of publications during their career, including articles, books, and book chapters. The quantity of papers in indexed journals and of article citations in the ISI/Web of Science and Scopus databases was evaluated. The articles published in journals with an impact factor were also assessed. Evaluation of the academic career was based on the number of supervised researchers, including scientific initiation students and masters, PhD, and postdoctoral researchers.

The data were organized on a spreadsheet (Microsoft Excel) and then analyzed with the Statistical Package for the Social Sciences (SPSS Inc., Chicago, Illinois, United States) program for Windows, version 21.0. A descriptive statistical analysis was performed and the absolute frequency and percentage of the variables investigated were calculated. Regarding bibliometric data (number of scientific articles, number of supervised students and researchers, and publications and citations indexed in the databases) the mean, median, and Interquartile Ranges (IQ) were calculated between the percentiles 25 and 75 .

\section{RE S U L T S}

The curricula of the 80 investigated productivity research grant/CNPq research fellows in the Nutrition field were as follows: $67.5 \%$ $(n=54)$ were female; $51.2 \%$ held a degree in Nutrition, and the remaining had degrees in Medicine (26.2\%), the Biological Sciences $(8.8 \%)$, Pharmacy $(2.5 \%)$, or Physical Education $(2.5 \%)$. There were no senior fellows, and $52.5 \%$ were classified as Level 2 (Table 1).

The researchers considered in the study came from 13 different Brazilian states (Table 2). Approximately two-thirds (65.0\%) were from the Southeast region, with $36.3 \%$ working in São Paulo, $17.5 \%$ in Rio de Janeiro, and $11.3 \%$ in Minas Gerais. In the Northeast region, where $21.3 \%$ of the researchers were found, $15.0 \%$ worked in Pernambuco. The lowest percentage of researchers was recorded in the South and Center-West regions $(11.3 \%$ and $2.6 \%$ respectively). Productivity research grant/CNPq research fellows in the area of Nutrition in the Northern region were not identified.

Analysis of the researchers' affiliations showed that $26.3 \%$ of them were from the Universidade de São Paulo (USP), 12.5\% from the Universidade Federal do Pernambuco (UFPE), $7.5 \%$ from the Universidade Federal de São Paulo (Unifesp), 7.5\% from the Universidade Federal do Rio de Janeiro (UFRJ), 6.3\% from the Universidade Federal de Santa Catarina (UFSC), 6.3\% from the Universidade do Rio de Janeiro

Table 1. Distribution of research productivity fellows in nutrition according to data collected between October 2014 and February 2015 and following the categorization by the Conselho Nacional de Desenvolvimento Científico e Tecnológico.

\begin{tabular}{lcc}
\hline Productivity grants category & $\mathrm{n}$ & $\%$ \\
\hline 2 & 42 & 52.5 \\
1D & 22 & 27.5 \\
1C & 4 & 5.0 \\
1B & 5 & 6.3 \\
1A & 7 & 8.8 \\
Senior & 0 & 0.0 \\
\hline Total & 80 & 100 \\
\hline
\end{tabular}

Source: http://www.cnpq.br/documents/10157/5f43cefd-7a9a-40 30-945e-4a0fa10a169a 
Table 2. Geographic distribution (states of the federation) of Conselho Nacional de Desenvolvimento Científico e Tecnológico research productivity fellows in Nutrition based on data collected between October 2014 and February 2015.

\begin{tabular}{lcccc}
\hline State of the Federation & $\mathrm{n}$ & $\%$ & Population $^{*}$ & Grants/Million inhabitants $^{\text {(2) }}$ \\
\hline São Paulo & 29 & 36.3 & $44,749,699$ & 0.65 \\
Rio de Janeiro & 14 & 17.5 & $16,635,996$ & 0.85 \\
Pernambuco & 12 & 15.0 & $9,410,336$ & 1.27 \\
Minas Gerais & 9 & 11.3 & $20,997,560$ & 0.43 \\
Santa Catarina & 5 & 6.3 & $6,910,553$ & 0.72 \\
Rio Grande do Sul & 4 & 5.0 & $11,286,500$ & 0.35 \\
Distrito Federal & 1 & 1.3 & $2,977,216$ & 0.34 \\
Bahia & 1 & 1.3 & $15,276,566$ & 0.06 \\
Rio Grande do Norte & 1 & 1.3 & $3,474,998$ & 0.29 \\
Piauí & 1 & 1.3 & $3,212,180$ & 0.31 \\
Mato Grosso do Sul & 1 & 1.3 & $2,682,386$ & 0.37 \\
Ceará & 1 & 1.3 & $8,963,663$ & 0.11 \\
Alagoas & 1 & 1.3 & $3,358,963$ & 0.30 \\
\hline Total & 80 & 100.0 & $206,081,432$ & 0.14 \\
\hline
\end{tabular}

Source: *Instituto Brasileiro de Geografia e Estatística [21].

(UERJ), 3.8\% from the Universidade Federal de Viçosa (UFV), 3.8\% from the Universidade Federal de Minas Gerais (UFMG), and 3.8\% from Universidade Estadual de São Paulo (Unesp) (Table 3).

With respect to the researchers' experience after completing their PhDs (stricto sensu), the mean was 18 years ( $\mathrm{IQ}=10-39$ years). Among them, 38.8\% attended the stricto sensu program at the USP and $10.0 \%$, the Unifesp, representing, therefore, almost half of the PhDs. More than half of the researchers (58.8\%) conducted postdoctoral studies, most of them abroad. Regarding the area of specialization described in the curricula, $27.2 \%$ of the professionals worked in nutrition, $22.0 \%$ in nutrition biochemistry, $12.5 \%$ in epidemiology, $7.5 \%$ in public health, and $5.0 \%$ in maternal and child health.

Analysis of the ratio of the number of productivity research grant fellows per inhabitant showed that the national average was 0.14 per million inhabitants. The states of Bahia and Ceará showed a lower ratio than the national average, with an average of 0.06 and 0.11 per million inhabitants respectively. The average of the other 11 regions was much higher than the national average, varying between 0.29 and 1.27 researchers per million inhabitants.

The productivity indexes displayed in Table 4 show the descriptive measures of the publication of scientific articles of productivity research grant/CNPq research fellows in Nutrition and of their participation in the training of human resources. During the period of the academic career considered in the study, the researchers published 7,358 articles in scientific journals, ranging from 25 to 310 articles per researcher (median=84 articles per researcher, $\mathrm{IQ}=53-285)$.

Among the articles published over the period, 3,316 (approximately 45\%) were indexed in the ISI/Web of Science database (median=33 per researcher; IQ=32-161) and 4,542 articles (about 62\%) were indexed in the Scopus database (median $=48.5$ per researcher; $\mathrm{IQ}=37-204)$. It was observed that 5,166 articles (70\%, median=61 per researcher, $\mathrm{IQ}=34-205)$ were published in journals evaluated by the impact factor index. 
Table 3. Distribution of Conselho Nacional de Desenvolvimento Cientifico e Tecnológico research productivity fellows in Nutrition by institution based on data collected between October 2014 and February 2015.

\begin{tabular}{|c|c|c|}
\hline Higher education institution & $\mathrm{n}$ & $\%$ \\
\hline Universidade de São Paulo & 21 & 26.3 \\
\hline Universidade Federal de Pernambuco & 10 & 12.5 \\
\hline Universidade Federal de São Paulo & 6 & 7.5 \\
\hline Universidade Federal do Rio de Janeiro & 6 & 7.5 \\
\hline Universidade Federal de Santa Catarina & 5 & 6.3 \\
\hline Universidade do Estado do Rio de Janeiro & 5 & 6.3 \\
\hline Universidade Estadual Paulista & 3 & 3.8 \\
\hline Universidade Federal de Minas Gerais & 3 & 3.8 \\
\hline Universidade Federal de Viçosa & 3 & 3.8 \\
\hline Universidade Federal de Pelotas & 2 & 2.5 \\
\hline Universidade Federal Fluminense & 2 & 2.5 \\
\hline Instituto de Medicina Integral Professor Fernando Figueira & 2 & 2.5 \\
\hline Universidade Federal de Ouro Preto & 2 & 2.5 \\
\hline Universidade Federal da Bahia & 1 & 1.3 \\
\hline Universidade Federal do Rio Grande do Norte & 1 & 1.3 \\
\hline Universidade Federal do Rio Grande do Sul & 1 & 1.3 \\
\hline Universidade de Brasilia & 1 & 1.3 \\
\hline Universidade Federal do Piauí & 1 & 1.3 \\
\hline Universidade Federal do Mato Grosso & 1 & 1.3 \\
\hline Universidade Federal de Ciências da Saúde de Porto Alegre & 1 & 1.3 \\
\hline Universidade Federal de Alagoas & 1 & 1.3 \\
\hline Universidade Federal do Ceará & 1 & 1.3 \\
\hline Universidade do Vale do Rio dos Sinos & 1 & 1.3 \\
\hline Total & 80 & 100.0 \\
\hline
\end{tabular}

Table 4. Descriptive measures of the publication of scientific articles and training of human resources based on data from Conselho Nacional de Desenvolvimento Científico e Tecnológico research productivity fellows in Nutrition collected between October 2014 and February 2015.

\begin{tabular}{llccc}
\hline Variables & \multicolumn{1}{c}{ Production Modes } & Quantity & Mean & Standard Deviation \\
\hline Publication of scientific articles & Scientific articles & 7,358 & 91.98 & 46.870 \\
\hline Human resources supervision & Scientific Initiation supervision & 1,746 & 21.83 & 18.053 \\
& Masters supervision & 1,847 & 23.09 & 12.970 \\
& PhD supervision & 775 & 9.69 & 7.640 \\
& Postdoctoral supervision & 72 & 0.90 & 1.658 \\
\hline Total & & 4,440 & 55.50 & 29.100 \\
\hline
\end{tabular}

The researchers' publications were cited 31,585 timesin the WoS database (median=256.5, $\mathrm{IQ}=397-2.351$, from 1 to 2,352 citations) and 48,318 in Scopus (median=409, IQ=509-3.704; 3,706 quotes). The median of the most cited article in WoS was 50 citations (IQ=68-701), and in Scopus was 59 citations ( $\mathrm{IQ}=55-866)$.

Evaluation of the academic career over the period of the study showed that the researchers supervised 1,746 scientific 
initiation fellows (median=20, IQ=20-106) and 1,847 masters (median=21.5, IQ $=16-68$ ) and $775 \mathrm{PhD}$ theses (median=8; IQ=10-36), as well as 72 postdoctoral projects (median $=0.1 ; \mathrm{IQ}=1-8$ ) (Table 4).

\section{DISCUSSION}

This study provides scientific production indicators for productivity research grant/CNPq research fellows in Nutrition and identifies some characteristics that help to characterize this population. In Brazil, both as a science and as a profession, Nutrition is a relatively new field [22]. Therefore, the collected data are essential for a current analysis of this area of knowledge. Although a previous study showed an increase in the number of nutrition researchers and scholars between 2000 and 2008 [23], the present study is unprecedented with respect to analyzing data from the curricula of productivity research grant/CNPq research fellows available on the Lattes Platform. The latter is a national standard system in the registration of the academic and professional activities of the scientific community implemented and maintained by the Brazilian government for the management of information of an internationally recognized quality related to researchers, institutions, and research activities in the country. Although the curricula currently available on the Lattes Platform are considered a standard for the evaluation of researchers [24], this system has some limitations since the information is provided by the users. Thus, the accuracy of the information, as well as its updating, depends exclusively on the researchers.

Regarding the analysis of the profile of the productivity research grant/CNPq researchers in Nutrition, a predominance of females was observed. Analysis of the profile of the performance of nutritionists in Brazil performed by the Federal Nutrition Council in 2005 identified a feminization of the profession, with $96.5 \%$ shown to be women. The predominantly female performance among productivity research grant/CNPq fellows was also reported in the areas of Nursing [10] and Physiotherapy [25], which also share the characteristic of being dominated by females. In this study, however, it was not possible to associate the greater participation of women exclusively with the nutritionist profession since many of the evaluated researchers graduated in other areas, especially Medicine. According to Guedes et al. [26], the country's general situation reflects how men continue to represent the majority of the grant holders, although there is a clear trend of greater numbers of female researchers, suggesting a change in this scenario. It is also necessary to consider the multidisciplinary nature of postgraduate courses in nutrition, which receive health professionals from different backgrounds and different ratios of men and women.

Most of the productivity research grant/ $\mathrm{CNPq}$ nutrition researchers are located in the Southeast region of Brazil, especially in the state of São Paulo, consistent with studies on researchers in other areas of knowledge $[12,13,27]$. This fact may be related to the historical concentration of graduate courses in nutrition in this region $[1,7]$. Historically, the first seven institutions to create undergraduate courses in nutrition in Brazil were the USP, the Universidade Federal do Estado do Rio de Janeiro, the Universidade do Estado do Rio de Janeiro (UERJ), the UFRJ, the Universidade Federal da Bahia (UFBA), the UFPE, and Universidade Federal Fluminense (UFF) [1]. These institutions nowadays hold most of the productivity research grant/CNPq researchers in Nutrition in the country, and this should be associated with the fact that they have been working in this area for longer periods. The distribution of Brazilian scientific production in different areas of knowledge varies in different regions of the country [28], reinforcing the results of this study on Nutrition.

According to Sacco et al. [16], surveys that show gender disparities in professional performance and in the distribution of researchers 
and research grants at different institutions are required to reevaluate the distribution of their resources. These authors also stress that the surveys should be carried out periodically to evaluate the evolution of productivity indicators and the area as a whole. It is also important to emphasize the need to develop networks of scientific collaboration in the formulation of science, technology, and innovation policies in Brazil since this integration promotes the quality and regional expansion of scientific activity and, consequently, the development of less favored regions [28].

The relative number of productivity research grant/CNPq research fellows in Nutrition (per million inhabitants) is still low compared to areas like Medicine [11] and Chemistry [29]. This can be expected since the area of Nutrition is relatively new. With its expansion, it can be expected that the number of researchers in the area will increase as well as the resources allocated for research.

The productivity of the scientific community can be evaluated by quantitative bibliometric indicators, reflected in the number of publications and impact indicators, which are based on the number of citations of publications, characterizing the importance of this scientific production according to the recognition granted by other researchers [18]. The impact factor is also used by funding agencies and by CAPES to qualify professionals and degrees, as well as to qualify and define research policies [30]. A study on scientific production in nutrition by Vasconcelos [31], published by the SciELO according to an evaluation by the CNPq, analyzed the scientific production of nutrition and found that most of the publications (62.4\%) had no impact factor, as measured by Journal Citation Reports. In this study, the bibliometric data on the productivity research grant/CNPq researchers in Nutrition were much more expressive, reaching $70.0 \%$ of articles published in journals with an impact factor. This indicates that to achieve quantitative indicators of quality, the publications were not restricted to specific Nutrition periodicals. It is suggested that future studies should evaluate the main journals selected by productivity research grant/ CNPq researchers in Nutrition and their selection criteria.

Along with the publication of scientific articles, the training of human resources is an important criterion for the evaluation of candidates for research grants [14,32]. As expected for productivity research grant/CNPq researchers, those evaluated in the present study were qualified to train new professionals. This was confirmed by the number of supervisions carried out, from scientific initiation to postdoctoral studies, which can be considered to be high when compared to the results of studies on human resources training in Brazil in the areas of Nursing [13] and Pediatrics [33].

The results allow for a better understanding of Nutrition and can assist in the devising of strategies for new investment policies to enhance the country's overall scientific production.

\section{CONCLUSION}

The productivity research grant/CNPq research population in nutrition considered in the period of the study showed a predominance of female fellows and of category 2 researchers. The researchers were found to be concentrated in the Southeast region of the country. The publication of $70 \%$ of the scientific articles in impact-oriented journals indicates the influence of Brazilian nutrition research on society and its potential for influencing food and health public policies.

New studies with similar methodologies may be important for characterizing the Brazilian scientific production in the Nutrition field and other areas of knowledge since there are few national studies on the profile of the scientific production generated by CNPq scientific productivity fellows. In addition, for a more practical application of the 
results yielded, a continuation of the present study should contemplate the impact of the publications according to different themes in nutrition, identifying the strengths and weaknesses that should lead the way with respect to incentives for new research projects.

\section{CONTRIBUTORS}

$\mathrm{L}$ PINHO contributed to the design and execution of the study, the data analysis and interpretation, and the writing of the article. $\mathrm{H}$ MARTELLI-JÚNIOR and EA OLIVEIRA contributed to the design and planning of the study, the data analysis and interpretation, and the writing and revision of the article. DRB MARTELLI, H MARTELLI-JÚNIOR and EA OLIVEIRA contributed to the design and planning of the study, the data analysis and interpretation, and the writing and revision of the article.

\section{R E FER E N C E S}

1. Vasconcelos FAG, Batista Filho M. História do campo da alimentação e nutrição em saúde coletiva no Brasil. Ciênc Saúde Coletiva. 2011;16(1):81-90. https://doi.org/10.1590/S1413-8 1232011000100012

2. International Food Policy Research Institute. Global nutrition report 2014: Actions and accountability to accelerate the world's progress on nutrition. Washington (DC): International Food Policy Research Institute; 2014 [cited 2014 Jan 30]. Available from: http://www.ifpri.org/sites/ default/files/publications/gnr14.pdf

3. World Health Organization. Millennium development goals. Fact sheet, $n^{\circ}$ 290. Geneva: WHO; 2015 [cited 2015 May 29]. Available from: http://www. who.int/mediacentre/factsheets/fs290/en/\#

4. Kac G, Proenca RPC, Prado SD. A criação da área "nutrição" na CAPES. Rev Nutr. 2011;24(6):905-16. https://doi.org/10.1590/S1415-5273201100060 0011

5. Coordenação de Aperfeiçoamento de Pessoal de Nível Superior. Portaria $n^{\circ} 83$, de 6 de junho de 2011. Diário Oficial da União. 2011 8 jun [acesso 2016 dez 6]; (109):12; Seção 1. Disponível em: https://www.capes.gov.br/images/ stories/download/avaliacao/avaliacao-n/Portariacapes-83-2011.pdf

6. Olinto MTA, Lira PIC, Marchini JS, Kac G. Formação humana, pesquisa e produção cientí- fica na submissão de avaliação "nutrição" da Coordenação de Aperfeiçoamento de Pessoal de Nível Superior, no Brasil, de 2007 a 2009. Rev Nutr. 2011;24(6):917-26. https://doi.org/10.1590/ S1415-52732011000600012

7. Vasconcelos FAG. The construction of scientific knowledge in food and nutrition: Analysis of dissertations and theses in the Brazilian postgraduation programs in Nutrition. Rev Nutr. 2015;28(1):5-16. https://doi.org/10.1590/1415-5 2732015000100001

8. Conselho Nacional de Desenvolvimento Científico e Tecnológico. Produtividade em Pesquisa (PQ). Brasília: CNPq; 2014 [acesso 2014 out2]. Disponível em: http://cnpq.br/documents/10157/5f43cefd-7a 9a-4030-945e-4a0fa10a169a

9. Mugnaini R, Jannuzzi PM, Quoniam L. Indicadores bibliométricos da produção científica brasileira: uma análise a partir da base Pascal. Ciênc Inf. 2004;33(2):123-31.

10. Santos SMC, Lima LS, Martelli DRB, Martelli Junior H. Perfil dos pesquisadores da Saúde Coletiva no Conselho Nacional de Desenvolvimento Científico e Tecnológico. Physis. 2009;19(3):761-75. https:// doi.org/10.1590/50103-73312009000300012

11. Martelli Junior $H$, Martelli DR, Quirino IG, Oliveira MCL, Lima LS, Oliveira EA. Pesquisadores do $\mathrm{CNPq}$ na área de Medicina: comparação das áreas de atuação. Rev Assoc Med Bras. 2010;56(1):478-83. https://doi.org/10.1590/S010 4-42302010000400024

12. Oliveira $M C L$, Martelli DRB, Pinheiro SV, Miranda DM, Quirino IG, Leite BGL, et al. Perfil e produção científica dos pesquisadores do Conselho Nacional de Desenvolvimento Cientifico e Tecnológico na área de Pediatria. Rev Paul Pediatr. 2013;31(3):278-84.

13. Santos MIP, Silveira MF, Oliveira EA, Martelli DRB, Dias VO, Veríssimo FM, et al. Avaliação da produção científica, patentes e formação de recursos humanos da Enfermagem Brasileira. Rev Bras Enferm. 2015;68(5):846-54.

14. Mendes PHC, Martelli DRB, Souza WP, QuirinoFilho S, Martelli-Júnior H. Perfil dos pesquisadores bolsistas de produtividade científica em medicina no CNPq, Brasil. Rev Bras Educ Med. 2010;34(4):535-41.

15. Moreira JR, Vilan-Filho JL, Mueller SPM. Características e produção científica dos grupos de pesquisa do CNPq/DGP nas áreas de Ciência da Informação e Museologia (1992-2012). Perspect Ciênc Inf. 2015;20(4):93-106.

16. Sacco AM, Valiente L, Vilanova F, Wendt GW, DeSousa DA, Koller SH. Perfil dos Bolsistas de Produtividade em Pesquisa do CNPq atuantes em 
Psicologia no Triênio 2012-2014. Psicol Ciênc Prof. 2016;36(2):292-303.

17. Conselho Nacional de Desenvolvimento Científico e Tecnológico. Bolsas. Brasília: CNPq; 2015 [acesso 2015 jun 29]. Disponível em: http://www.cnpq.br/ web/guest/bolsistas-vigentes

18. Silva JA, Bianchi MLP. Cientometria: a métrica da ciência. Paidéia. 2001;11(21):5-10. https://doi. org/10.1590/S0103-863X2001000200002

19. Conselho Nacional de Desenvolvimento Científico e Tecnológico. Currículo Lattes. Brasília: CNPq; 2014 [acesso 2014 out 2]. Disponível em: http:// buscatextual.cnpq.br/buscatextual/busca.do? metodo=apresentar

20. Cavalcante RA, Barbosa DR, Bonan PRF, Pires $\mathrm{MBO}$, Martelli-Júnior $\mathrm{H}$. Perfil dos pesquisadores da área de odontologia no Conselho Nacional de Desenvolvimento Científico e Tecnológico (CNPq). Rev Bras Epidemiol. 2008;11(1):106-13.

21. Instituto Brasileiro de Geografia e Estatística. Gerência de estudos e análises da dinâmica demográfica 2000 a 2012: projeção da população do Brasil e das unidades da federação, por sexo e idade para o período 2000-2030. Rio de Janeiro: IBGE; 2015 [acesso 2016 dez 13]. Disponível em: http://www.ibge.gov.br/home/estatistica/ populacao/projecao_da_populacao/2013/default. shtml

22. Conselho Federal de Nutricionistas. Inserção profissional dos nutricionistas no Brasil. Brasília: CFN; 2006 [acesso 2016 dez 5]. Disponível em: http:// www.cfn.org.br/pesquisa.pdf

23. Prado SD, Bosi MLM, Carvalho MCVS, Gugelmin SA, Silva JK, Delmaschio KL, et al. A pesquisa sobre alimentação no Brasil: sustentando a autonomia do campo Alimentação e Nutrição. Ciênc Saúde Coletiva. 2011;16(1):107-19. https://doi. org/10.1590/S1413-81232011000100015

24. Amaral R, Brito A, Rocha K, Quoniam L, Faria L. Panorama da inteligência competitiva no Brasil: os pesquisadores e a produção científica na plataforma Lattes. Perspect Ciênc Inf. 2016;21(4):97-120.

25. Sturmer G, Viero CCM, Vieira MN. Profile and scientific output analysis of physical therapy researchers with research productivity fellowship from the Brazilian National Council for Scientific and Technological Development. Braz J Phys Ther. 2013;17(1):41-8.

26. Guedes MC, Azevedo N, Ferreira LO. A produtividade científica tem sexo? Um estudo sobre bolsistas de produtividade do CNPq. Cad Pagu. 2015;45:367-99. https://doi.org/10.1590/18094 449201500450367

27. Santos NCF, Candido LFO, Kuppens CL. Produtividade em pesquisa do CNPq: análise do perfil dos pesquisadores da química. Quím Nova. 2010;33(2):489-95.

28. Sidone OJG, Haddad EA, Mena-Chalco JP. A ciência nas regiões brasileiras: evolução da produção e das redes de colaboração científica. Transinformação. 2016;28(1):15-32.

29. Vasconcelos FAG, Calado CLA. Profissão nutricionista: 70 anos de história no Brasil. Rev Nutr. 2011;24(4):605-17. https://doi.org/10.1590/S141 5-52732011000400009

30. Toffoli GA, Ferreira SMSP. Mapeamento da produção científica de pesquisadores brasileiros de ciências da comunicação: período de 2000 a 2009. Psicol USP. 2011;22(2):399-422. https://doi. org/10.1590/S0103-65642011000200007

31. Vasconcelos FAG. The scientific production of Nutrition published by the Scientific Electronic Library under the gaze of the evaluation of the Coordination for the Development of Higher Education Personnel. Rev Nutr. 2017;30(2):147-61. https://doi.org/10.1590/1678-9865201700020 0001

32. Valle $M E$, Sakuray $F$. On the criteria for receiving a research productivity fellowship from the Brazilian National Council for Scientific and Technological Development in Mathematics. TEMA. 2014;15(3):237-48.

33. Gonçalves E, Santos MIP, Maia BT, Brandão RCS, Oliveira EA, Martelli-Júnior $\mathrm{H}$. Produção científica dos pesquisadores da área de pediatria no CNPq. Rev Bras Educ Med. 2014;38(3):349-55. https:// doi.org/10.1590/S0100-55022014000300009

Received: January 23, 2017 Final version: October 4, 2017 Approved: October 24, 2017 